\title{
Towards a cultural geopolitics: on the making of a documentary- poetry film about a post-conflict place
}

\author{
JAMES RIDING AND JACK WAKE-WALKER
}

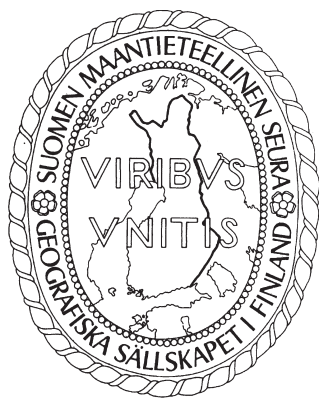

Riding, James \& Jack Wake-Walker (2017). Towards a cultural geopolitics: on the making of a documentary-poetry film about a post-conflict place. Fennia 195: 1, pp. 61-84. ISSN 1798-5617.

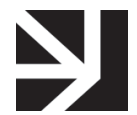
Made in collaboration with an independent filmmaker and two poets, the documentary-poetry film Bridges <Bosnia 20> presents life in post-conflict Bosnia-Herzegovina, and delivers a clear message: the war in Bosnia is not yet firmly located in the past. Shot through a computer screen, Bridges <Bosnia 20> forces the viewer to witness the war in Bosnia and its aftermath via-the-gaze of an unknown spectator, sitting on an Apple Mac laptop. Through this modern technological distancing, we re-present here images of war in a digital age, question how war is usually packaged and represented on television, and in turn interrogate, through poetry, how war is traditionally remembered and memorialised. In so doing, Bridges <Bosnia 20> leads us to a conclusion, in Srebrenica, in 2015: in order to invest in the possibility of a just future after conflict, it is necessary to acknowledge the unthinkable realities to which traumatic experience bears witness.

Watch the film Bridges <Bosnia 20 $>$ here and visit the Bridges $<$ Bosnia 20 $>$ website for more information

Keywords: cultural geography, geopolitics, film, poetry, conflict, memory

James Riding, RELATE Centre of Excellence, Kanslerinrinne 1, University of Tampere, Tampere, Finland FI-33014, E-mail: james.riding@uta.fi

Jack Wake-Walker, independent filmmaker, website: http://www. jackwakewalker.com/, Copenhagen,Denmark,E-mail:jack@wake-walker.com

I spent my childhood and youth on the outskirts of the Alps, in a region that was largely spared the immediate effects of the so-called hostilities. At the end of the war I was just one year old, so I can hardly have any impressions of that period of destruction based on personal experience. Yet to this day, when I see photographs or documentary films dating from the war I feel as if I were its child, so to speak, as if those horrors I did not experience cast a shadow over me... I see pictures merging before my mind's eye - paths through the fields, river meadows, and mountain pastures mingling with images of destruction - and oddly enough, it is the latter, not the now entirely unreal idylls of my early childhood, that make me feel rather as if I were coming home... - W.G. Sebald $(1999,71)$

Only those who do not care, only those who find a way to diminish or extinguish the value of other human beings, survive wars without damage and speak of warrior honour afterward. - Aleksandar Hemon $(2013,114)$

In order to know, we must imagine for ourselves. - Georges Didi-Huberman $(2008,3)$ 


\section{Introduction: Watching war}

\section{Autumn 1994, Mostar [raw documentary footage, Stuart Laycock]}

There is a boy in a hospital bed who must be younger than ten years old. Two doctors are standing over him on the right of the screen. Their arms are reaching out towards the boy. A pillow is propping up the boy's leg, his right leg. In the background is a man also in a bed. His stomach is out and he is laid on his back. A doctor is attempting to place something into his mouth. The boy has two bandages on his eyes, big circular bandages. His chest also has a bandage strapped to it. A sound is heard from the man in the background. It is the sound of a deep breath and a retch, a gulp of air mixed with a cough. The noise you make when emerging from the sea after swimming, having swallowed some water. A tube makes its way down his throat.

The camera zooms in on the boy. We are closer to his face now. He has blood around his nose. The bandages almost cover his face. Circles of white bandage over his eyes. His small hand is bloody, wrapped and wrapped in bandages. He is breathing heavily, hyperventilating. The boy begins to speak, yet does not move. His head remains in the same position, on the pillow, facing the ceiling.

"Dada."

"Dada."

"Dada."

"Dada."

The camera zooms in on the heavily bandaged hand, shakes about and zooms out again. The boy swallows.

"Dada."

"Dada."

“Da...da."

"DADA."

“DADA."

A disembodied, emotionless voice says, "This little boy was playing with a hand grenade... It went off and it has taken his hand with it... He was also blinded... They are doing the best that they can... He will live but."

A feeling persisted as we sat and watched previously unseen documentary footage, snatched short fragments of film, taken during the war in Bosnia. The appetite for such images is of a vulgar or low appetite; that this article, and this small rescuing of lost videotapes depicting the Bosnian conflict is in some way implicated in a trauma-spectacle, a 'commercial ghoulishness' (Sontag 2004, 100). A 'commercial ghoulishness', which we felt we were in some way wound up in after watching images of a war that ended twenty years ago, and that all of this creative effort was perhaps a 're-traumatising' of survivors (Sontag 2004, 100; see Felman \& Laub 1992; Felman 2002; Jeffrey \& Jakala 2014). And speaking to this uneasy feeling that we had on watching conflict, in Watching war, Jan Mieszkowski (2012) echoing Jean Baudrillard (1994) - asked us to once again look at war as a spectacle unfolding before a mass audience. Mieszkowski (2012) implored us, as we sat in front of an Apple Mac laptop watching fragments of traumatic film, to ask what it means to be a spectator to war in an era where the boundaries between witnessing and perpetrating violence have become profoundly blurred. Death lends storytellers all their authority, as Walter Benjamin once wrote, and death sanctions this story (Arsenijević 2010, 2011; Benjamin 2016). Yet perhaps, as Damir Arsenijević $(2011$, 166) has written, such sanctioning is not enough. If we borrow from death, here, we also want to borrow from the life that is left after genocide, to evoke the unpleasant corporeal remainder, and to bear witness to genocide. It is for this reason that we return poetry to geopolitical writing, as a Romantic antidote to the spectacle of war. For 


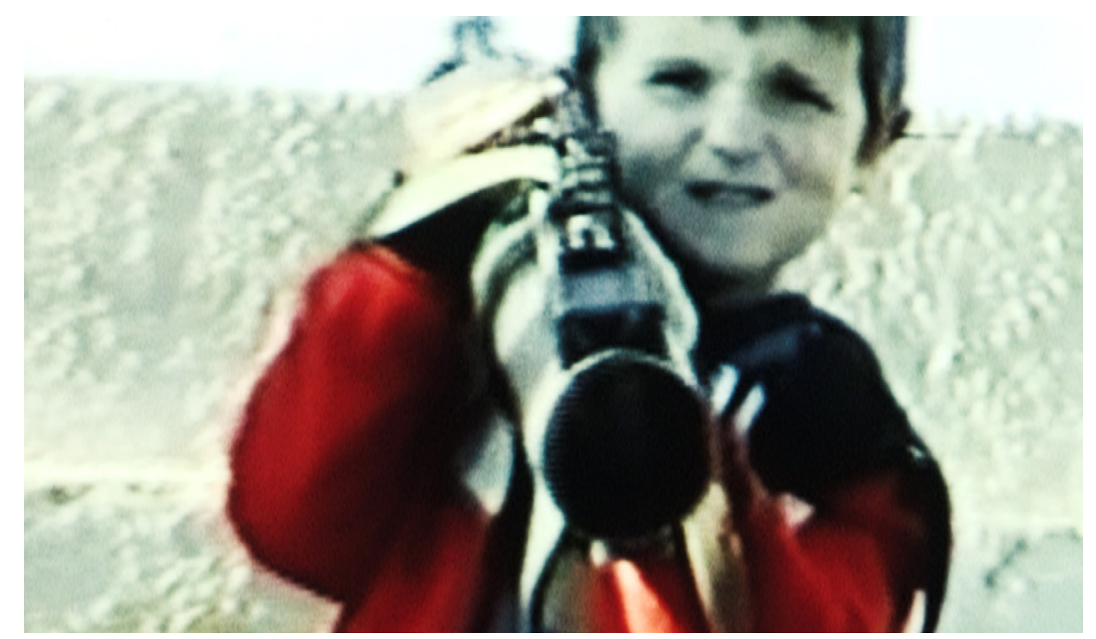

Fig. 1. Still from the documentary-poetry film Bridges $<$ Bosnia 20 $>$.

"poetry bears, powerful and politically productive witness to what the dominant politics in a society after genocide wants to foreclose" (Arsenijević 2011, 168). And we aim here, through the suturing together of poetry and traumatic images, to speak for those whom violence has deprived expression, historically reduced to silence; those citizens deprived of their human face (Felman 2002).

While throughout the documentary-poetry film Bridges $<$ Bosnia 20 $>$ - crafted from the traumatic images described in the opening of this article - we seek to represent and deconstruct our watching of these snatched fragments of footage, taken during the war in Bosnia, and to resist and yet emphasise the spectacle that war, trauma, and violence has become (Fig. 1). As such, we remember certain concepts and descriptions put forward fifty years ago by Guy Debord (1967) in La société du spectacle (Society of the spectacle), which are now more relevant than ever before in a digital age (see Boal et al. 2005). Shot through a computer screen - simulating the way in which we first encountered these traumatic images - Bridges <Bosnia 20> forces the viewer to witness the war in Bosnia and its aftermath via-the-gaze of an unknown spectator, watching war on a laptop screen. Through this modern technological distancing, Bridges <Bosnia 20> re-presents images of war in the new age of digital film, and it questions and deconstructs the usual packaging and representation of a war. For never before has conflict depended so much on a struggle for hegemony in the world of images, never before has the dominant world power been subject to real catastrophe in the realm of the spectacle (Boal et al. 2005). We live in a time - as Boal, Clark, Matthews and Watts (2005) in Afflicted powers: capital and spectacle in a new age of war and Mieskowski (2012) in Watching war remind us - in which violence is presented as a spectacle. Violence is the very thing which characterises our age; it feels disrespectful to be captivated by its strange charisma, and almost taboo to talk of an 'other', yet equally real narrative of the 'triumphant' past (see Väyrynen 2014). And perhaps, as David Rieff (2016) has written recently in a book on the cult of memory called In praise of forgetting: historical memory and its ironies - which argues collective remembrance can be toxic - it is indeed moral to stop remembering, to stop glorifying war, to stop circulating traumatic images (see also Rieff 2011). Or, at least now, it may be time to question how we consume images of trauma; how we watch war; how we understand geopolitics through a feedback loop of traumatic images - and to work with these geopolitical images sensitively and constructively in order to make a positive change in post-conflict places (Ingram 2009, 2011, 2012, 2016).

For we could not ignore or forget these images after first seeing them. And today, being a spectator of calamities taking place in another country is a quintessential modern experience; wars are also living room sights and sounds (Sontag 2004, 16). A new 'tele-intimacy' has occurred, during which "the understanding of war among people who have not experienced war is now chiefly a product of the impact of these images" (Sontag 2004, 19). This intimacy has only increased as images are now shared 
widely on the internet, capturing in film distant war-torn places. And while the cumulative diffusion of such violent images can sap our capacity to respond to horrific images with compassion, without their existence, the devastation of people and places would be unknown to others. For as we can 'see' now daily in Aleppo, a place under siege like Sarajevo was, "forgetting extermination is part of extermination", as journalists are increasingly prevented from entering conflict zones (Baudrillard 1994, 49; Jergović 2016). Indeed, the war in Bosnia was perhaps, the final war that was understood chiefly through the images captured and portrayed on television screens, and packaged by journalists reporting from a war zone: it was the last 'television war' (Baudrillard 1995; Toal 1996).

So we tell ourselves again and again that an unwillingness to engage with traumatic and violent images is worse; to ignore their existence is to sanction a history, and to turn away from the screen is to enter into a secret complicity with the aggressor. It is to collude in the plight and pain of others, in the instant of their trauma and its enduring aftermath (Sontag 2004). For a historic traumatic reaction to past violent events is well-known (Caruth 1995). As such, the previously unseen short films made by an aid-worker that fell into our hands - snatched moments between the delivery of medical aid - are worthy of contemplation for this reason alone. To retell a story of the war in Bosnia for survivors, for the people in the films, for the dead, and for a future for this post-conflict place beyond ethnic division (Bieber 2006; Belloni 2009; Toal \& Dahlman 2011; Jeffrey 2013).

And furthermore, in the place with which this article is concerned, Bosnia-Herzegovina, it is common to consider representations of the world (Crampton 1996; Campbell 1999). It is common to deconstruct meaning and symbolism (Campbell 1998), and it is common to consider via landscapes of meaning, the symbolic landscape (Cosgrove 1983, 1985, 2001, 2008; Cosgrove \& Daniels 1988). For there remains a persistent imaginary of this place, an imagined Balkans that is still seemingly pervasive. This imagined Balkans can be found in the opening lines of Misha Glenny's (1999) magnum opus, The Balkans, 1804-1999, where Bram Stoker's (1897) Dracula is said to be representative of an almost gothic region. In the old Orientalist tradition, it seems as if the Balkans occupies the centre of some sort of imaginative whirlpool, where every known superstition in the world is gathered (Glenny 1999).

Echoing the well-established literature on representations of the Balkans in literary studies and geography (e.g. Todorova 1997; Goldsworthy 1998), Mark Mazower (2002) details how this has come to be the case. Mazower (2002) argues that representations of the Balkans loaded the Balkans with negative connotations: inharmonious conditions, small antagonistic states, and hostile nationalities, all of which conspired to form the intractable Balkan or Eastern question (Carter 1977; Todorova 1997; Goldsworthy 1998; Glenny 1999; Horvat \& Štiks 2015). Writing of the Balkans as Europe's ghost, Slavoj Žižek (2000, 1-2) goes further. Down there, always somewhere a little further to the southeast, the Balkans are a photographic negative of what was until recently cast as a tolerant, multicultural, post-political, post-ideological Europe. A 'postmodern racism' exists, Žižek argues, where the Balkans are seen as the intolerant other, while the rest of Europe has supposedly come to terms with otherness in its much vaunted - indeed marketed - language of cosmopolitanism and multiculturalism (Žižek 2000, 1-2).

The task for us, as such, was always to travel outside of and beyond an ever-present ethnic and identitarian civic discourse, and to somehow craft, engrave, but not entomb a new identity for this place post-conflict (Campbell 1998, 15). And also, to build upon the aesthetic geopolitics forcefully brought forth by Alan Ingram (2009, 2011, 2012, 2016), and to speak back to Gerard Toal's (1996) feminist and post-colonial re-positioning of an 'anti-geopolitical eye', torn between anger and academia. With this in mind, the documentary-poetry film Bridges <Bosnia 20 $>-$ which this article goes on to describe the making of - sought to demonstrate that it is often the small, discrete, and apparently unimportant things that bear the most psychic weight, that imprison most pain (Sontag 2004; Riding 2017a). Humans live, and survive, in stories, in fragments of stories, and not the grand narratives of the historic record. When retelling and locating the trivial and ostensibly irrelevant details and moments of a traumatic past, a therapeutic intervention becomes meaningful. Via the transference of traumatic stories through art, it is possible to ease intense personal suffering and offer new possibilities for change in post-conflict communities (Riding 2017b). A change that would, as this article speaks of, acknowledge the unthinkable realities to which traumatic experience bears witness, in order to invest in the possibility of a just future after conflict (Arsenijević 2010, 2011). 


\title{
Cultural geopolitics
}

\author{
Spring 1995, Mostar [raw documentary footage, Stuart Laycock]
}

The snatched fragment of footage begins in a lorry about to cross a bridge. Not the old bridge, a bridge that looks temporary. It is made up of crisscrossing metal and has a wooden slatted floor. As the lorry approaches the bridge, a large concrete tower block can be seen on the opposite bank of the river. It is totally ruined, with no windows and bits hanging off. The bridge creaks as the wheels of the lorry crunch the wood. To the right is an old building, generally weathered by bullets and shells, its surface eroded. A steering wheel and the dashboard are briefly visible, along with the windscreen wipers, and two men can be seen at the end of the bridge. Filming stops suddenly... Down the road, buildings no longer have a façade - squat walls remain giving a brief outline of what it once was. A white car is parked up and two people get out. Standing still, they look at a mosque. Its roof is half gone, and the entrance is a hole. In the background, beyond the decapitated minaret, we can see a mountain with poplar trees dotted about. The camera is then put away, but is still recording...

As is conveyed in the following article, through a 'creative' geographical practice, it is possible to offer a critically oriented and intentionally disruptive perspective (Hawkins 2013a, 2013b, 2015a, $2015 b)$. Here via a critical-creative practice, an attempt is made to re-define and under-cut the stubborn regional schema associated with the implicit identitarian and ethnic territorial geopolitics of a particular region of the world (Toal \& Dahlman 2011; Jeffrey 2013; Horvat \& Štiks 2015). A region of the world where a simplistic tracing between state and territory, and politics and governance, undergirds the processes involved in the making and unmaking of political subjects and the attachments and detachments of space, politics, and citizens (Latour 2007; Brenner \& Elden 2009; Elden 2013; Agnew 2016). Informing and developing an ontopological account, which David Campbell $(1998,1999)$ identified in Bosnia-Herzegovina nearly twenty years ago, this article seeks to understand the situated geopolitics of a place, and via the merging of poetry and images, we seek to deconstruct and expand what is traditionally considered geopolitical research (Toal 1996). In so doing, we return the more obviously political to cultural geography, and also produce a cultural geography of the geopolitical, through advancing the notion of a 'cultural geopolitics' (Ingram 2009, 2011, 2012, 2016). A situated ontopological account, the article specifically seeks, here in postconflict Bosnia-Herzegovina, to represent those formerly Yugoslav citizens, who seek to deconstruct a fixed identitarian politics, and remove from below and within ethno-nationalist borders (Crampton 1996; Campbell 1999). Read against Campbell's (1998) Derridean analysis of the war in Bosnia eschewing the goal of an ethical theory in favour of an ethos of political criticism - this article is concerned to question and go beyond assumptions and limits of a traditional geopolitical theory, borrowing from phenomenological accounts of landscapes of conflict, trauma and memory (Taussig 2006; Riding 2015a, 2015b).

It does this via a critical-creative response, a documentary-poetry film called Bridges $\langle$ Bosnia 20 , which is positioned as a way of returning cultural geography to the vital socio-political agenda of the unfinished compositional project, 'new cultural geography' (Cosgrove \& Jackson 1987; Cosgrove \& Daniels 1988). A project, which drew upon a humanistic geography of Tuan, Relph, and Buttimer, and combined this humanism with Derridean and deconstructive work on representation, as can be seen in Berger's (1972) Ways of seeing (Cresswell 2010; Cosgrove 1983, 1985, 2001, 2008). Bringing a representational 'new cultural geography' concerned with images, maps and text, back into view in this article, is situated as an important task, in a place defined and fixed by its traumatic past, in order to think through arrangements of power and its affects (Cosgrove \& Jackson 1987; Cosgrove \& Daniels 1988). It is argued that the understanding and explanation of 'maps of meaning' remains an important task in Bosnia-Herzegovina, twenty years after ethnic conflict (Cresswell 2010). Yet we remember here, when in the face of war in Europe, the 'new cultural geography' did not act upon its initial revolutionary agenda (Cosgrove \& Jackson 1987; Cosgrove \& Daniels 1988). It neglected to write a 'new cultural geography', which considered ethnic conflict as it was taking place, and a war which was brought to an end through a geographical international relations theory (Campbell 1998). Indeed, there was a noticeable lack of research on the war in Bosnia in cultural geography during the 1990s 
(Toal 1996). As such, with this absence of other cultural geography on the collapse of Yugoslavia, this article writes now what could have been written decades earlier.

It was December 1995 when the war in Bosnia was brought to an end, and the Dayton Agreement was signed in Paris (Glenny 1992; Thompson 1992; Rieff 1995; Little \& Silber 1996; Campbell 1998). A 'peace' time has lasted to this day, although the framework agreement, which divided the country in roughly half along ethnic lines, has prevented Bosnia-Herzegovina from developing entirely beyond wartime divisions (Crampton 1996; Campbell 1999; Bieber 2006; Belloni 2009; Toal \& Dahlman 2011; Jeffrey 2013). Preceded by an agreement between Bosniaks and Bosnian Croats signed in Washington in 1994, the country was separated into two political entities: the predominantly Bosnian Serb, Republika Srpska, and the mainly Bosniak and Bosnian Croat, Federation of Bosnia and Herzegovina, sometimes informally referred to as the Bosniak-Croat Federation. Locally, the country is further separated out, as the Federation of Bosnia and Herzegovina has ten autonomous cantons with their own governments. Each canton is known as majority Bosnian Croat, majority Bosniak, or 'mixed' (Nancy 2000). Within the cantons are municipalities and homogenous enclaves, which further 'define' the individuals living there (Anderson 1983; Campbell 1998; Nancy 2000; Brubaker 2002). And while Republika Srpska is led more centrally from the de facto capital Banja Luka, there are still observable geographical divisions between the northern portion and southern portion of the state within a state. Which is often said to be under threat of being wiped off the map, acting in-place as a nationalising of civic discourse, nullifying any post-ethnic activism (Touquet 2012, 2015).

As such, there remains twenty years after the end of the war in Bosnia, a lack, a loss of a national imaginary beyond the lines drawn across the country by the Dayton Agreement, which was designed to be replaced (Gordy 2015). Indeed the idea of creating a prosperous post-conflict period was not factored into the discussions that took place in Dayton, Ohio; rather ending the war in Bosnia was the sole goal of the accords. Today each entity remains a state in-itself, as each entity of Bosnia-Herzegovina has its own government, flag, coat of arms, police force, customs, postal service, president and parliament or assembly. While a 2-km zone of separation runs on either side of the inter-entity border, making a 4-km zone in total stretching into both entities (Fig. 2). The border is not determined by geographical features, or an existing regional imaginary, rather it traces the front lines during the war

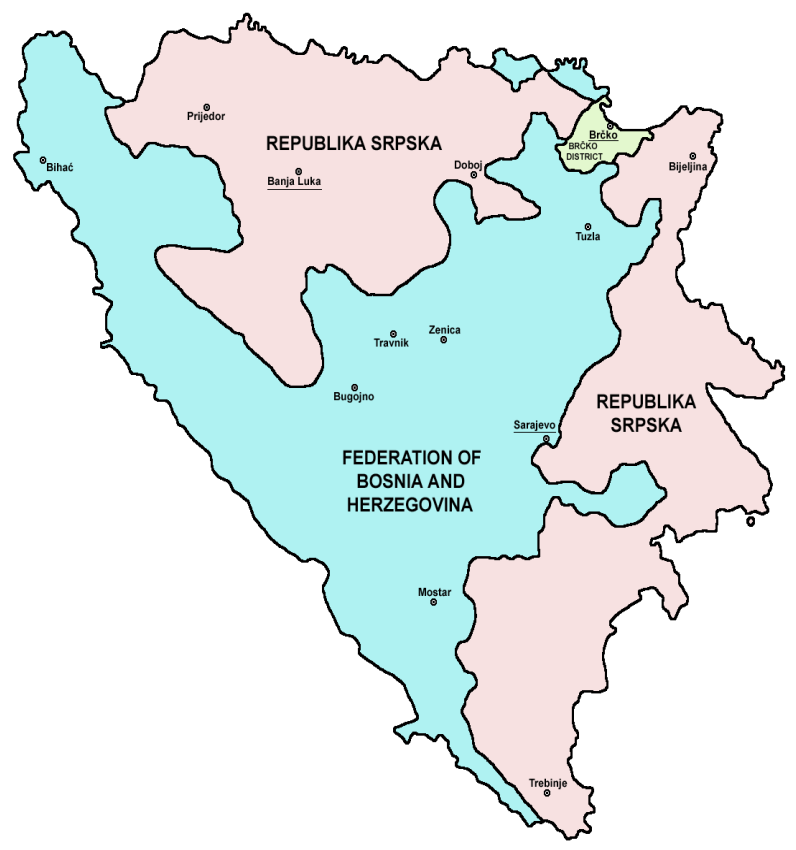

Fig. 2. Map of the inter-entity border. 
in Bosnia. The Dayton Agreement is as such, a political agreement based on a wartime ethnic division, causing many people to migrate from one entity to the other, or to never return home after being displaced during the war in Bosnia (Riding 2015a).

This cartographic representational idiosyncrasy, or more precisely 'apartheid cartography', enforces an ethno-nationalist overhaul of space upon individuals in Bosnia-Herzegovina (Crampton 1996; Campbell 1999). Cartography has aided a post-socialist era of never-ending 'transition', of brutal capitalism and diminished democracy, and the continuation of a nationalist governance that it was hoped would fade away (Gordy 2015). Twenty years after the end of the war in Bosnia, it is now evident - yet underreported by the 'cosmopolitan' Europeans guilty of Balkanism (Carter 1977; Todorova 1997; Goldsworthy 1998; Glenny 1999; Žižek 2000; Mazower 2002) - that the endless postconflict, post-socialist, 'transition' era of Bosnia-Herzegovina, has meant for citizens general impoverishment, de-industrialisation, mass unemployment, and a non-democratic rule of divisive and corrupt elites (Helms 2013; Arsenijević 2014; Gilbert \& Mujanović 2015; Hromadžić 2015; Jansen 2015; Kraft 2015; Kurtović 2015; Majstorović et al. 2015; Mujkić 2015; Murtagh 2016; Riding 2016a, 2017a).

Amidst this fractured geopolitical landscape, a cultural geographer in collaboration with an independent filmmaker and two poets created a film. This article accompanies, narrates, and deconstructs the making of that film. The aim of the film, called Bridges $\langle$ Bosnia 20 $\rangle$, is to confront a traumatic past in order to contemplate a forgotten future (Arsenijević 2010, 2011). In the process, an attempt is made through the creation of a film, to deconstruct ever-present ethnic and identitarian debates in Bosnia-Herzegovina (Riding 2017b). For there is within this documentary-poetry film and in the work of other artists in the first two decades of this century, working out of Bosnia-Herzegovina, a clear intention to be a human rights activist and an artist, enfolding art and activism to produce a form of art-activism (Riding 2017b). As such, the documentary-poetry film created has been publicised and mobilised in spaces across Bosnia-Herzegovina. A representation, it acts in-place as a public disavowal of the ethno-nationalist state(s), and a singular or 'pure' collective identity (Nancy 2000). In so doing, the documentary-poetry film reveals a need to work through Bosnia's past, yet also through this vital shared public mourning of a traumatic past, it conversely aims to affect the present (Arsenijević 2010, 2011). This is a radical undertaking in a society still under the heavy influence of ethno-nationalist politics in the post-conflict, post-socialist, 'transition' era, where a reduction or flattening of identity is a part of the state rhetoric (Arsenijević 2014; Horvat \& Stiks 2015). For the Bosnia-Herzegovina created post-conflict, demands, sets up and confirms ethnic division, and as such, we aim to deconstruct and breach this division, mourning in the process the loss of a multiethnic socialist Yugoslavia (Luthar \& Puznik 2010).

\section{Images in spite of all}

\section{Autumn 1993, Mostar [raw documentary footage, Stuart Laycock]}

Stuart Laycock is standing on a corner, in the open, facing a mountain. The camera is pointing into the distance. A road is turning away to the left from where he stands on the pavement. Two poplar trees reach up in the centre of shot, and two further poplars are on the very left hand edge of the image. In the distance a mountain with a quarry hacked into it covers the background. Above the rocky expanse, a dull sky is overcast. Rolling down the mountainside are the mists of an early morning, and a town is just about visible at the base of the jagged hills. The footage is shaky but remains focused on the same outcrop far ahead. We hear a voice, Stuart's mother. Four seconds into the film she says, "It is difficult to tell where the shelling is coming from isn't it... little bursts and it seems to echo... that's somewhere over on the left... that's single machine gun fire."

Stuart is now turned slightly more to the left, aiming roughly at where the noise is coming from. In shot is a sign with some writing on, indecipherable due to the angle we are looking from. After seventeen seconds, a louder and more piercing sound is heard above the talking.

"Yeah come on," Stuart's mother shouts.

"Fucking hell that was a bullet," shouts Stuart back. 
The camera twists quickly to the floor and we see a blur of long grass, then the lines in the middle of the road at an odd angle, then the pavement as the camera is pointed to the floor, then Stuart's arm and shirt, as the camera is pulled close to Stuart's chest, jumping about as he runs.

"Keep that running and move," Stuart's mother tells her son.

A button on a stripy shirt is all that is now visible and a laugh is overheard. The camera is less jumpy as the pace slows to a walk. After forty-three seconds a car can be overheard driving by, but is not seen.

In autumn 1992, Stuart Laycock travelled to Bosnia-Herzegovina for the first time. After crossing the English Channel on the car ferry, he drove across Europe, down the coast of Croatia, and entered BosniaHerzegovina near Tomislavgrad. The van he was driving was full of high-value medicine, new antibiotics and anaesthetics, including insulin and the vital blood-clotting agent, factor eight. On this trip he took some photographs. After autumn 1992, Laycock realised that he needed a video camera to document the war that was taking place, and to reveal what was happening to others, in the form of moving images. So twice a year, for the next three years, he carried a video camera when he delivered aid.

Over twenty years later, feeling that enough time had passed, Laycock took the videotapes that he had made on these trips out of the attic. He did not really want to watch them but at the same time, he did not want them to be lost. Inevitably, as he got the boxes out of the attic, he watched what was on the videotapes. These videotapes, cherished possessions, captured and portrayed events that shaped his life, and a war. He began the task of going through each tape, getting them out of their boxes and putting them into the machine. It did not matter that they had been left in a box for years and that they remained there, unwatched. They were there, and so was a link to his past, and a visual history of the collapse of Yugoslavia was safe. The intense condensing of the past into a series of moving images became a kind of witnessing, in the moment of watching his younger self and memories came flooding back. Some memories had been forgotten, some suppressed, and others became newly shaped by what he was now seeing on screen.

These forgotten tapes are some of the last videotapes of Yugoslavia, taken in the last days, depicting its collapse (Glenny 1992; Thompson 1992; Rieff 1995; Little \& Silber 1996; Campbell 1998). As an archive of fragmentary footage, the chronological and geographical reach of the films is immediately apparent. Laycock was in the north, south, east and west of the country, he was there only a few months after the war in Bosnia began, and the last films are shot weeks after the Dayton Agreement (Gordy 2015). Yet, as becomes apparent when watching these snatched images, it is his amateur eye, capturing his everyday existence in a war zone, which is vital to the films created. The films display in their entirety the seemingly inconsequential and inadmissible, the apparently irrelevant things in and stories from a country at war.

"In our haste to measure the historic, significant and revelatory, let's not leave aside the essential: the truly intolerable, the truly inadmissible", writes Georges Perec (2008: 209) in an essay called Approaches to what?. It matters to Perec that the questions he asks, barely indicative of a method, let alone a project, seem trivial and futile. This is precisely what makes them essential, this is precisely why they matter more than so many of the other kinds of questions we have tried to ask, or been trained to ask. In Place Saint-Sulpice, a square in Paris, he sits in one cafe, then another, for three days, recording everything that passed his field of vision (Perec 2010). As such Perec's attempt at exhausting a place in Paris, aims to describe all the things that usually go unnoticed (Perec 2010). It is an attempt to document what he had previously called L'Infra-ordinaire - the infra-ordinary - the background noise, the habitual, the stuff that is looked over, missed when gazing at a scene (Perec 2008). And is, as such, a critical examination of what draws and escapes our attention. We take Georges Perec seriously here in a region that has slipped off the radar of geographical endeavour since the end of the war in Bosnia. And we borrow his 'way of seeing' when watching the films Stuart Laycock made in Bosnia-Herzegovina, recording the minor details of the scene and the 'small stories' of the ordinary people present within them (Berger 1972; Lorimer 2003).

We do this for an important reason. In the process of attempting to represent a traumatic past, speaking of seemingly incidental moments, and remembering the little details of a place - a location, an apartment, or a bus journey - enables a series of associative memories to occur. In Freud's early 
writings on trauma, this form of testimony is specifically seen as a way to allow a traumatic event to be 'forgotten' (Riding 2017a). For this reason, telling and re-telling a life-story may be a part of the cure, the giving-up of an important reality, or for a psychoanalyst, "the dilution of a special truth into the reassuring terms of therapy" (Caruth 1995: vii). Present within the short films that Stuart Laycock captured are Bosnian Croats, Bosniaks, and Bosnian Serbs, all receiving aid and speaking on camera at different points during the war, and on the films are bits of Bosnia-Herzegovina that rarely appeared on the nightly news broadcasts from 1992 to 1995. There are scenes that seem to linger and last too long, witnessing the traumatised people of a war-torn country, made all the more vital and essential, because they are taken by someone who is not a trained cameraman. Shaky, oddly framed, unedited, they have an almost intolerable quality. Nothing mediates the obvious trauma of those filmed, and nothing directs or 'guides' our viewing of them. The fragments of footage are for this reason more real and shocking, more disturbing and far more proximate than the packaged moving images often seen in the filming of distant war-torn regions on television. Here are 'snatched images' from a country at war, images squeezed between or snatched either side of the task-at-hand, the delivery of medical aid (Didi-Huberman 2008).

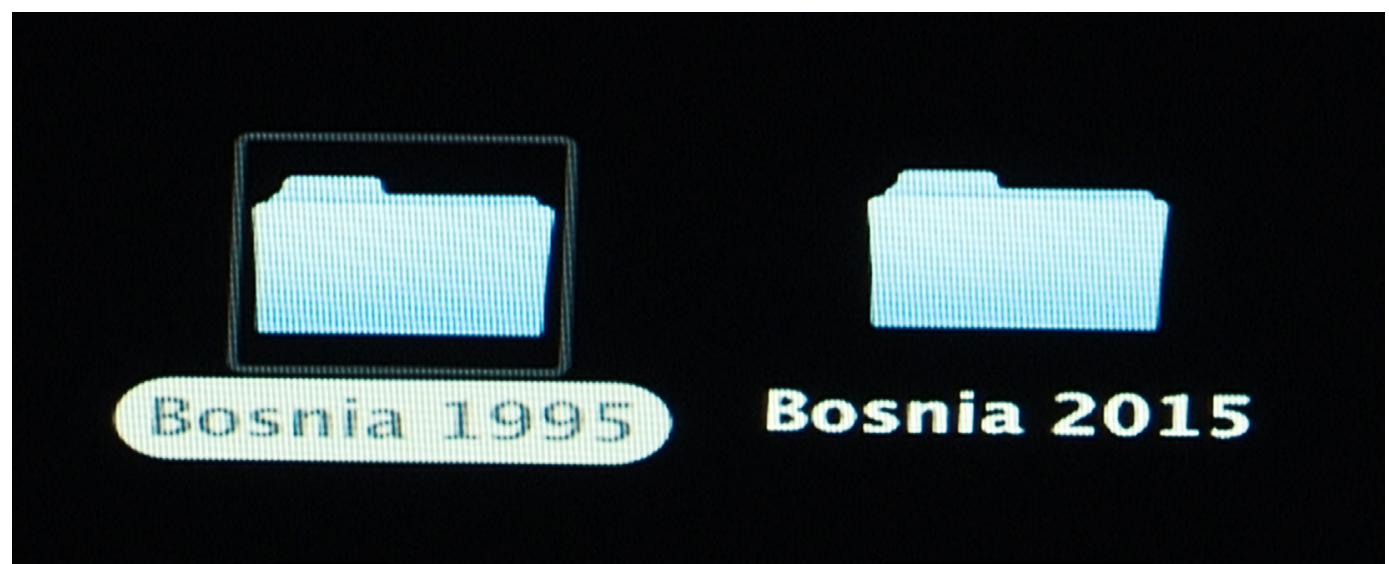

Fig. 3. Still from the documentary-poetry film Bridges $<$ Bosnia 20 $>$.

It is from these 'snatched images' that we began the task of making a film about a place twenty years after ethnic conflict (Didi-Huberman 2008). The documentary-poetry film created, Bridges $\langle$ Bosnia 20 $\rangle$, delivers a clear message: the war in Bosnia is not yet firmly located in the past (Toal \& Dahlman 2011; Jeffrey 2013; Horvat \& Štiks 2015). Shot through a computer screen, the very images Stuart Laycock gathered during the war in Bosnia are re-presented in Bridges <Bosnia 20>. And the viewer is forced to witness the war in Bosnia and its aftermath via-the-gaze of an unknown spectator, sitting on a laptop in the comfort of their home. We initially see the mouse cursor on the laptop screen moved between two files: Bosnia 1995 and Bosnia 2015 (Fig. 3). This is from where the opening scene of the film begins, as a click on the former file, Bosnia 1995, opens a video-box to reveal never-before-seen footage of the war in Bosnia taken by Stuart Laycock over twenty years ago. And we see the bullets fired from a mountain in Mostar, while standing on a corner filming in the valley below.

After seeing the short films again, twenty years after the traumatic events that took place, Stuart Laycock decided to write a book of poetry about his experiences in Bosnia-Herzegovina during the war (Laycock 2015). Bridges <Bosnia 20> begins with the short film described above, capturing a divided Mostar, which is seen after a click on the video-box, Bosnia 1995, and quickly moves to a journey through a landscape of half-destroyed houses which fill the screen. Matter-of-fact poetry, written by the very author of this footage, Stuart Laycock, describes and soundtracks the images re-presented. The words are cold and deliberate, as if almost factually reporting the scenes that are unfolding. While the images are harsh, emotional, and desperate. 
The poem, Gone (Laycock 2015), reflects back upon the delivery of medical aid to Bosnian Serb refugees who had reached the town of Prijedor in northwest Bosnia-Herzegovina. On his way, he passed through the typical rolling green hills of the region, now eerie, uncanny, desolate landscapes, or 'deathscapes', as each house that slid by through the window had been systematically targeted and destroyed (Maddrell \& Sidaway 2010). The poem begins, "The speed sign still warns us to slow down for a village where no village exists anymore", and ends with, "If one single house, just one, still lived, big or small (it wouldn't matter which) then death would not be absolute, the pain not half so dark" Real sounds, real cries, and real interviews from the time taken by Stuart Laycock make this poetic narration all-the-more real, yet our imaginary viewer still clicks and views the devastation through the grainy pixels of their smart laptop. And through this modern technological distancing, Bridges $<$ Bosnia $20>$ aims to re-present images of war in a digital age, deconstructing these images on the screen. In turn, borrowing from poets who attempted to rob war of its last shred of glory, Bridges <Bosnia 20> interrogates through the use of poetry, the way in which we have traditionally remembered and memorialised war (Baudrillard 1994; Sontag 2004; Mieszkowski 2012; Rieff 2016).

Another poem by Stuart Laycock follows, called Don't mean, and asks the question, what was all this slaughter was for? The poem reveals the struggle faced for a poet to make sense of what he witnessed during the war in Bosnia. And it reveals the futility of war, subverting the grand narratives of the dominant politics in a society after genocide - the fixed historic record - ending with,

\section{Could we cope}

if grimy suspicion grabbed us

grubby with frontline dirt,

reaching from the soil

like a bony hand

partly skin-covered,

that death don't mean anything?

\section{I declare this poem a safe zone}

\section{Winter 1995, Prijedor [raw documentary footage, Stuart Laycock]}

The war in Bosnia had just ended. The film begins with ruined houses passing by one after the other, roof missing, windows gone, as Stuart drives food and supplies for refugees north. He stops at a refugee camp and begins filming again as boxes are unloaded from a van. "It was bitterly cold, it was snowing, many of the houses had no glass in them, this horse was being stabled in what used to be a shop, and the refugees were queuing in the snow," Stuart's mother says over the images.

The camera is pointed at a young girl. She is wearing a red jumper and is visibly cold, hunching her shoulders and pushing her arms into her pockets and close to her body. She has a dark brown bob of hair. She looks into the distance beyond the camera.

"They've lost absolutely everything... They've lost their friends," says a voice.

The girl looks into the camera. Her mouth is clenched together, her eyes sad, knowing.

"But they've lost more than that... They've lost their childhood... Their childhood has been lost," says the same voice again.

The girl looks up and speaks.

"This little girl is fourteen years old... She says her childhood is gone," the voice translates.

The girl speaks again.

"In 1992 she left the house in Bihać and she has been a refugee since then," we hear, as the moment Stuart captured on film ends. 
It is common to construct a certain geopolitical narrative in order to write of the former Yugoslavia. Work draws on either ethnographic data collected to explore state-building and post-conflict reconstruction (Jeffrey 2006), or, through a form of discourse analysis work interrogates the loss or dispossession of identity, deconstructing the internal skirmishes of ethnic and identitarian debate (Campbell 1998). Borrowing from a non-representational (Thrift 2008), embodied (Ingold 1993), landscape geography (Wylie 2007), and extending the 'new cultural geography' (Cosgrove \& Jackson 1987; Cosgrove \& Daniels 1988), this poetic article drifts somewhat against the more established geopolitical discourses associated with research on the collapse of Yugoslavia (Glenny 1992; Thompson 1992; Rieff 1995; Little \& Silber 1996; Campbell 1998), the post-socialist 'transition' era after Yugoslavia (Toal \& Dahlman 2011; Jeffrey 2013; Horvat \& Štiks, 2015), and the Balkans more widely (Carter 1977; Todorova 1997; Goldsworthy 1998; Glenny 1999; Žižek 2000; Mazower 2002). And in so doing, we follow instead the trail of another, more grounded, descriptive, 'everyday', or 'cultural' version of the geopolitical (Bunge 1971; de Certeau 1984; Holloway \& Hubbard 2000; Bennett \& Watson 2002; Scott 2009). To travel and write outside of and beyond these more 'spectacular' or established geopolitical discourses - "discourses through which the representation, conduct and resolution of the war were sought" (Campbell 1998, 15) - is as Georges Perec (2010) notes, to follow the trail of another, more 'essential' history (Riding 2017a). A great number, if not the majority, of the things in Stuart Laycock's films of Bosnia-Herzegovina have been "described, inventoried, photographed, talked-about, or registered" (Perec 2010, 3). If possible, our intention, following in the footsteps of Perec was to "describe the rest instead" (ibid., 3).

So we began to film ourselves in Bosnia-Herzegovina, in the locations that were represented in the snatched fragments Stuart Laycock captured, during the war in Bosnia. And the film Bridges $<$ Bosnia 20> jumps forward twenty years. A click on the latter file, Bosnia 2015, and we see the aftermath of the war: memorials to children who never made adulthood, the remains of corpses in Srebrenica - still being interred so long after genocide. And around all of these images, a more emotional, lamentable, and humanistic poetic narration from the poet Simon Barraclough rises to a crescendo, as a mother weeps for a child she should never have survived (Barraclough 2008, 2010, 2011, 2015; Barraclough et al. 2013). The poem, I declare this poem a safe zone, speaks to the uneasy feeling we had on first watching these traumatic snatched fragments of film. The 'commercial ghoulishness', which we felt we were in some way wound up in after watching images of a war that ended twenty years ago, and the worry that we were in some way involved in a 're-traumatising' of survivors (Sontag 2004, 100; Felman \& Laub 1992; Felman 2002; Jeffrey \& Jakala 2014). Reaching a high point, the speed at which the poem is delivered increases as the poet repeats and repeats, would you mind if I used,

\section{Would you mind if I used your death as exemplum - your pelvis as my virtual reality headset - your shinbone as the spine for my thesis - your dried tears for endnote indicators - your dental records as my ISBN - your ribs as my sergeant's stripes - your howls in a bombed-out home as my ringtone?}

Yet by the end of the poem Barraclough still seems to hold on to some hope, believing in the redemptive qualities of poetry after conflict,

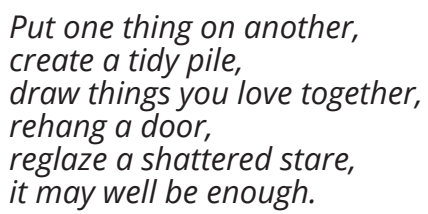

In the final scene of the documentary-poetry film, the past is shown to be enfolded within the present created, as any attempts to historicise the war in Bosnia, to consider it the past, have proved difficult, 
whilst a time of continuing unease persists (Baillie 2013). It is here that we realise the motives behind making a film about this place, as trauma necessarily yet persists and Bridges $<$ Bosnia 20$\rangle$ delivers a clear message: the war in Bosnia is not yet firmly located in the past (Toal \& Dahlman 2011; Jeffrey 2013; Horvat \& Štiks 2015). The video-box then freezes and all of what we have previously viewed shuttles by, time seems to stop and what is past and present is unclear - the viewer is now back in their pixelated reality, yet perhaps a human fire is now burning.

\section{Humanism from a mass grave}

Spring 1994, near Gornji Vakuf [raw documentary footage, Stuart Laycock]

7. 3. $94.12: 55$.

The road is a muddy track. A convoy is winding through the densely wooded hills of central Bosnia. It appears to be coming up to what was a checkpoint. The barrier is up and a little hut, looking like a kiosk where someone might sell sandwiches, or cigarettes, is unmanned. There is a turn ahead. A sign is visible in the background with an arrow on it. Taking up most of the screen is the vehicle ahead. It is a tractor pulling a large gun. The gun is being removed from the frontline, withdrawing troops. Bosniak soldiers sit on the back of the tractor and hang on to the giant gun. Two soldiers are standing on the back of the tractor, and three soldiers are sitting on the gun itself.

"Peace, etc., etc.," Stuart says.

The corner is approaching, and the soldiers start to wave at the camera as they turn. We can now see the side of the vehicle and the gun. A soldier leans backwards in his seat lifting his legs up, as he waves. He looks young. Another soldier, who was previously looking away, turns to look at the camera for the first time.

"Peace is breaking out all over," Stuart's mother says.

The camera then shifts to the right, away from the soldiers. Looking at a sign, the scene is shaky as the lorry bumps along the track. The sign has the Bosnian lily on it, an arrow pointing right and the names of some places.

SARAJEVO

TUZLA

ZENICA

TRAVNIK

NOVI TRAVNIK

BUGOJNO

Fifteen seconds have passed in early March 1994 on the roads of Bosnia-Herzegovina. Croats and Bosniaks had stopped fighting only days earlier, agreeing to a ceasefire. Soldiers and weapons are being pulled back from the frontline. The war would continue for another year and a half after this moment in time and place.

It was early 2014 before we finally reached the border of Bosnia-Herzegovina. Yet it seemed to hold some sort of connection to our own pasts, having growing up with the country on television, over two decades ago (Glenny 1992; Thompson 1992; Rieff 1995; Little \& Silber 1996; Campbell 1998). Images of emaciated inmates on the nightly news reached England where we sat in front of little television screens, watching what British journalists had revealed to the world (Vulliamy 1994, 2013). The memory from childhood contained moving images of what we later found out to be detention camps: Trnopolje, Omarska, and Keraterm. First unveiled in August 1992, they soon lit up televisions thousands of miles away, in all corners of the globe (Campbell 1998). Images of concentration camps again in the rural hinterlands of Europe shocked viewers and shook their conscience. Being so young, we 
understood little of why people were behind barbed wire, why they were starving, or who these people were. We recently rediscovered these films, and we remembered the moment of our first seeing these snatched images on television. While preparing for our own journey through BosniaHerzegovina, we were constantly asked: Why does it concern you? You are not from there. We have, perhaps, become so desensitised to images of suffering and trauma in distant regions on rolling news that it seems strange to say that as children, we were affected by what we witnessed on television in 1992 (Sontag 2004; Butler 2010).

Taking our childhood memories of a war-torn country as a starting point, we traced the line that now divides the country roughly in half. Passing by monumental memorials built to collectively mourn World War II, Bridges <Bosnia 20> eventually reaches and remembers the mostly unmarked sites of detention camps in use during the war in Bosnia, seen on television as children years earlier. These camps - Omarska, Trnopolje, and Keraterm - have since been cleared away and evidence of war crimes covered up; a simultaneous politics of denial and a cultivated remembering has taken place in this regionally altered land (Riding 2015a). Commemorative practices, of course, often reflect and consolidate the interests of power, in so far as the past becomes leashed to the services of new state and nation building (Hung 1991; Young 1993; Esbenshade 1995). Such power is revealed in discrete parts of Bosnia-Herzegovina through the absence of monuments; what is absented from sight here reveals an official narrative, reflecting the interests of those in power.

Yet, as is witnessed in Bridges <Bosnia 20>, these sites of non-remembrance, lacking any official state monument, have become sites of intervention where memory is a means to promote change and challenge the current political system. This dissident form of remembering has been explored elsewhere by Jenny Edkins (2003). In an attempt to escape the context in which they occur, a country that has been separated along ethnic lines since the series of secessionist wars that occurred in the final decade of the previous century, these acts of remembering are freed from their collective and nation-building capacities. And remembering conflict is instead reclaimed by the more discrete, idiosyncratic valences of the individual voice. In the process, the body - dehumanised by the traumatic event - has been recuperated by individuals who see it as necessary to the work of mourning (Butler 2010). A vulnerability and susceptibility to violence and abuse is precisely why using the body to commemorate is a vital and powerful counter-narrative to the material representations reinforcing nationhood. Specifically, the bodily act of commemoration becomes a counterpoint to the tendency in post-conflict regions to constantly collectivise the individual voice, a voice that was perceived as animal howl for those that reside in the mass grave (Arsenijević 2011).

As the twentieth anniversary of the genocide in Srebrenica passes, sites of mass murder remain unmarked to this day. It is in Srebrenica, amongst the lines and lines of pristine white gravestones, where the documentary-poetry film Bridges <Bosnia 20> ends, in 2015 (Fig. 4). Here we see that returning to the site of a traumatic event on a commemoration day is not only an act of remembrance. Commemorative events are gatherings of the wounded; they are insistent re-enactments of the past, where mourners bear witness to the testimony of survivors (Caruth 1995). In his memoir Postcards from the grave, Srebrenica survivor Emir Suljagić (2005) argued for the existence of a new Europe, a new European imaginary, where Auschwitz and Srebrenica are a part of the same human - or inhuman - story. And as Guido Snel (2014) observed - in his examination of spatial metaphor and the persistence of imaginary European geographies post-1989 - Suljagić was at pains to associate his experience in Srebrenica with the events that took place in the Third Reich's extermination camps. The Holocaust - a moral touchstone for inhumanity and banal evil - influenced the way Suljagić interpreted ethnic persecution, and the failure of the European world to identify with his personal position revealed to him the persistence of a separate Balkan regional imaginary: the war in Bosnia is not a part of the European story.

For Susan Sontag $(2004,101)$ though, it was intolerable, for to set the sufferings of the people of Bosnia alongside the sufferings of others is to 'compare' them, denigrating human life; this might well lead to a kind of competition between mere comparables. Though we argue, here, Suljagić's memoir was a targeted questioning of 'what is deemed necessary' to commemorate as part of the European story. For the 'cosmopolitan' Europeans, Bosnia was not their tragedy (Nancy 2000). Emir Suljagić was evacuated from Srebrenica in 1995, before the spa town was overrun. Almost every man he had ever known subsequently lost their lives in the genocidal massacre. 


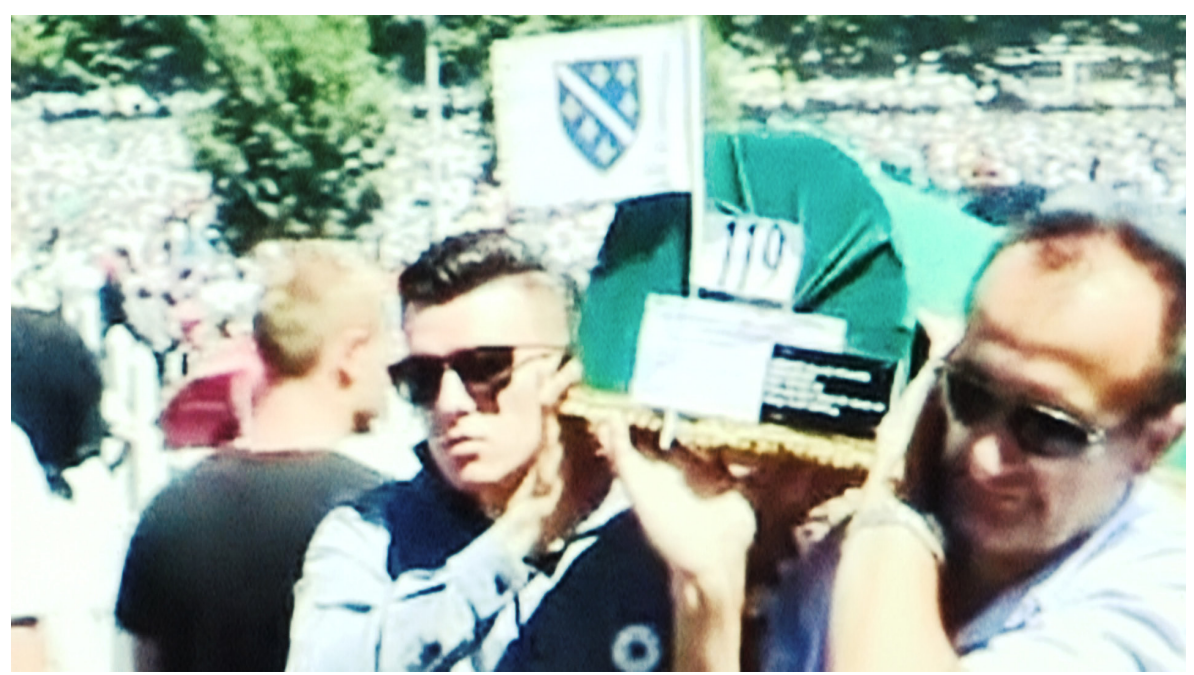

Fig. 4. Still from the documentary-poetry film Bridges $\langle$ Bosnia 20>.

\section{The ground of the image}

\section{Spring 1994, Mostar [raw documentary footage, Stuart Laycock]}

The scene begins with a man in a bed covered with a black and grey woollen blanket. His head is towards the left of the screen, his feet towards the right. He is wearing a blue hat and has a big moustache. Behind him is a wall of what looks like cupboards. The camera moves down the bed towards his foot, which is attached to a makeshift frame. The assemblage of metal and bandages woven through discs enables the leg to be elevated. Despite hearing the word "No," the man lifts up the covers to slowly reveal his leg.

As the blanket is pulled back, Stuart asks, "What has happened to him?"

"Grenade," replies the doctor.

His leg is slowly shown to Stuart. A doctor comes over to help the man lift the black and grey cover. Stuart zooms in on the leg, so that all that is now visible is a leg. Protruding from the shin of the man is a metal object, screwed into the skin and bone.

"Those are external fixations, there is shrapnel in the knee," says Stuart's mother.

A doctor walks in front of the man and his leg as Stuart zooms out. He sees the foot of the man poking out from behind her. Stuart begins to slowly zoom in on the bruised foot. The footage becomes shaky as the doctor walks out of shot. The video camera is turned off after thirty-eight seconds.

The scene begins with a woman in a bed wearing a cheque shirt and looking towards the camera. There are some tubes winding around her. A plastic shopping bag, with the letters ' $\mathrm{P}$ ' and ' $\mathrm{O}$ ' written on it is also sat on the bed. A brown blanket is pulled up to the woman's chest. She has thick brown hair and eyebrows. Her expression is dismal, just completely dragged down.

"Sniper," says the doctor.

Stuart asks, "Where was she hit?"

"In the chest, chest wound," replies Stuart's mother.

The woman blinks a few times and looks away from the camera, uncomfortable being filmed. A 
doctor walks between Stuart, the camera, and the woman we are focused upon. The woman looks down towards her chest, bringing her chin downwards. The doctor begins to reach under the brown cover and lifts up the cheque shirt that the woman is wearing. With her hand the doctor points with a finger at a square bandage on the woman's chest.

"Metak," the pointing doctor says.

There is/was a danger that in re-presenting the films that Stuart Laycock made in Bosnia-Herzegovina, we reproduce a Balkanism, a voyeuristic, unreflective and distanciated gaze - a gaze which has for centuries worked to create a European 'other' (Riding 2015a, 2016a). These concerns are attentive to a visual and cartographic discipline - geography - with an uncomfortable imperial and military history, "littered with the skeletons of murderous neglects and encounter" (Robinson 2003, 277). Both postcolonial and feminist perspectives on the situatedness of knowledge and the concomitant relational nature of researcher positionality have done much to avoid replicating these sorts of colonial-era power relations (England 1994; Rose 1997). And attentive to this work, we aim here to avoid such a Balkanist account, voyeuristic, unreflective and distanciated, by grounding these images. We retell and visualise the story of our watching of them in Bridges $\langle$ Bosnia 20 $\rangle$, and describe here something of their production, their maker, as well as the places in which the films were made, looking again and again at the moving images on the screen (Didi-Huberman 2008).

Images continuously pass our field of vision, as Georges Perec (2010) witnessed in Place SaintSulpice. Images confront and proliferate in the places humans inhabit. They capture, represent and define distant places and people; they travel and seem ubiquitous, ungrounded. Yet the way images are made is a situated knowledge, a product of a particular time and place. Drawing upon Michel Foucault's (1975) studies on the connections between knowledge and power, geographers have revealed that images have a certain geography and images create a certain geography (Rose 2012; Cosgrove \& Daniels 1988; Cosgrove 1983, 1985, 2001, 2008), as can be seen in the power of maps (Harley 1989; Wood 1992). The key to working with images for the visual anthropologist Sarah Pink $(2001,76)$ is "an understanding of the social relations and subjective agendas through which they are produced and the discourses through which they are made meaningful."

Moving beyond a 'representational' understanding of images common in the 'new cultural geography' (Cosgrove \& Daniels 1988), here we consider The ground of the image, from where Jean-Luc Nancy (2005) describes images as groundless, flat but receding spaces: if anything marks the image, it is a deep ambivalence. What hides in the depths and recesses of images? What secrets are concealed within the images? (Fig. 5). Of video Nancy $(2005,74)$ writes,

We must not even speak any longer of a screen: video is not of the order of the screen, but of penetration... Video means "I see"... Thus, in video, there is absorption in vision, with a tendency toward making absent what is seen... The seer and the viewer come before the visible.

As such, in Bridges $\langle$ Bosnia 20>, we would like to present what is seen - re-present what is seen - and we play upon the oddity of technological images, and digital film, by speaking of and displaying the screen that we are watching the short snatched fragments of film on. For video "is embedded into the material of the screen, it is not placed upon it as in cinema, nor is it physically joined with a canvas as in painting" (Nancy 2005, 73).

In so doing, we look at these moving images today "in terms of their phenomenology, even if it can only be restored incompletely", as the art theorist Georges Didi-Huberman $(2008,41)$ writes when looking at four photographs from Auschwitz. We are undertaking a kind of visual criticism, but not one 'disciplined' by any nameable theory or methodology, treating the films as a site of research in which we are situated and implicated after watching. As in much other phenomenological landscape geography (Dubow 2001, 2011; Wylie 2002, 2005, 2007; Lorimer 2003, 2006, 2012; Edensor 2005, 2008; Daniels 2006, 2012; Pearson 2006; DeSilvey 2007, 2010, 2012; Matless 2008, 2010, 2014; Lorimer \& Wylie 2010; Rose 2012; Riding 2015a, 2015b, 2016b, 2017b), the films analysed here, are treated not as a spatial gaze or a representational schema, overarching and constructing the traumatised landscape, rather they are considered as presentations that are 'in and of the world' (Dewsbury et al. 2002). For the films Stuart Laycock made, demand us to simultaneously tighten our point of view and widen our point of view (Didi-Huberman 2008, 41). We must tighten our point of view and attempt to 


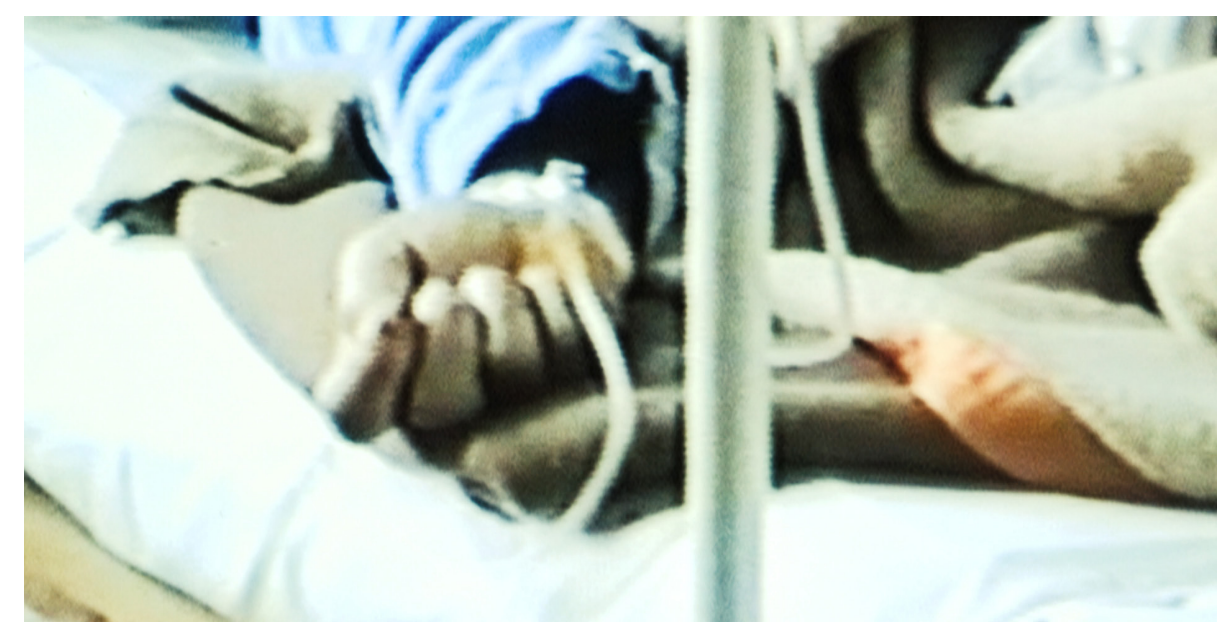

Fig. 5. Still from the documentary-poetry film Bridges $<$ Bosnia 20 $>$.

omit nothing of what is captured in the original films, even when facing something that seems empty of informative value, and there is seemingly nothing to see or nothing happens. Symmetrically they demand us to widen our point of view, to restore the anthropological value of the films, as films which reveal within themselves "a dilution of a special truth", a giving up of stories, or more precisely, testimony (Caruth 1995: vii).

In short, we suggest here that in retaining the impulse of phenomenological investigation - as the snatched fragments of film themselves, and the traumatised landscapes of Bosnia-Herzegovina demand - we are performing a more discrete, small, and intimate version of the political (and geopolitical) (Toal 1996). For the wider geopolitical landscape is inseparable from the scenes described here and the footage that is re-presented in the documentary-poetry film Bridges $\langle$ Bosnia 20>. In so doing, this article obliquely attends to the more obviously political (and geopolitical), which some critics of the embodied, phenomenological, or non-representational geography that emerged after the 'new cultural geography' (Cosgrove \& Jackson 1987; Cosgrove \& Daniels 1988), have cautioned, can be glossed (Castree \& Macmillan 2004; Van Dyke 2013). This paper, as such, speaks to and argues for a 'new' form of geopolitics through an 'opening up' of methodological approaches, and it also contributes a different way of writing and performing geopolitics imaginatively (Ingram 2009, 2011, 2012, 2016; Mitchell \& Kallio 2017). For remembering conflict, writing a geopolitical account, is often presented as a definitive, official narrative of the past, a record of the history of a place and conflict. In contrast, we argue that any account of a place and a conflict can never be truly complete. The figure of Parrhesiastes - the one who speaks the truth - haunts what we write and re-present in film, as we can present only fragments of a past, put together only in part: captured moments of human experience during conflict (Väyrynen 2013). And Bridges <Bosnia 20> informs and develops the kinds of ontopological accounts that Campbell $(1998,1999)$ identified nearly twenty years ago, by presenting images of place during conflict and post-conflict as a series of impressions, which re-present conflict not as a linear easily represented historical or geographical narrative. In contradistinction to a traditional geopolitical account, we re-present a fragmentary human history, for humans live and survive in stories, and not the grand narratives of the historic record.

\section{Conclusion: Regarding the pain of others}

\section{Autumn 1994, Travnik [raw documentary footage, Stuart Laycock]}

A young man is sat in the passenger seat of Stuart's lorry. Behind the young man, through the windscreen of the lorry, is a street in Travnik with trees flanking it on the far side. Behind the right 
shoulder of the young man, through the side window of the lorry, the clean stone wall of a building and a Volkswagen camper van is just about visible. A little car passes, driving along the street on the right of the screen. It looks like a little old Fiat, but it isn't.

The young man has short dark brown hair, and is wearing a wooly jumper with three stripes around the chest. It is dark in the cab of the lorry, so his face is in shadow, though we can see the outline of his face, ears, and he has a fringe. He is probably in his late teens.

"I tell you about situation in Travnik... Situation in Travnik, it's very difficult... Erm..."

He shrugs his shoulders and shifts about on the seat, and looks down in thought at nothing in particular, though seems to concentrate on a particular spot.

“... Every second we expect a grenade... Because..."

He pauses, takes a breath, and swallows, and again shrugs his shoulders, this time stretching his mouth as he does so, almost grimacing.

"... Grenade it kill the people... And..."

He is now looking directly into the camera.

"... It killed two of my friends."

He looks down, and up again quickly, back towards the camera.

“... And people be afraid of grenades..."

A woman and a man walk into shot. They are walking down the opposite side of the street. The woman is wearing a brightly coloured top.

“... People keep the shelter, or something like that..."

The people walk out of shot on the right. Two elderly women walk from behind the right shoulder of the young man, to the left of the screen.

“... And we hear just one noise, a grenade, we stay twenty-four hours in shelter."

Remnants of the past remain embedded in, buried beneath, strewn amongst, enfolded within, and are dimly recognisable in the present (Dymitrow 2017). Wartime - a time of continuing unease (Baillie 2013) - persists in the cartographic idiosyncrasy of the Dayton Agreement, imposed on the citizens of a small nation in Europe twenty years ago (Gordy 2015). As such, the documentary-poetry film Bridges $<$ Bosnia 20> makes a second clear statement: in order to ease personal suffering and to open new possibilities for change in individuals and communities who have experienced psychic trauma, there is a need to tell others of that traumatic history (Riding 2017a). If the traumatic past is not fully interrogated, the traumatic event itself cannot become a 'narrative memory' and be integrated into a story of the past. The speaking of trauma, giving voice to the incidents and accidents of the everyday and representing a traumatic life may well be a form of recovery. Telling someone about the past seems to be - and is certainly - for many survivors a way of stilling and surviving the recurrence of traumatic haunting (Caruth 1995). As Laub $(1995,63)$ notes, "Survivors do not only need to survive to tell their stories; they also need to tell their stories in order to survive." Likewise, "Our memory repeats to us what we have not yet come to terms with; what still haunts us" (Erikson 1995, 184). For this reason, Bridges <Bosnia 20> places, describes and reflects upon the use of testimony - informing, grounding, and locating a nascent psychoanalytic geography (Pile 1991, 1996; Bondi 1999; Nast 2000; Callard 2003; Philo \& Parr 2003; Kingsbury 2004; Kingsbury \& Pile 2014) - positioning testimony as an inherently geographic psychoanalytic technique, which not only eases suffering in individuals and communities, but offers new possibilities for societal change and transitional justice in post-conflict places.

Since the collapse of Yugoslavia, research in post-conflict places has begun to recognise the necessity of testimony - listening to and responding to traumatic stories - as a means to alleviate 
suffering for individuals and communities (Caruth 1995; Riding 2017a). Yet when undergoing psychoanalysis there is always a certain inaccessibility - the inaccessibility of trauma to be simply located, dated, or even understood by those who were not there. Though through different modes of encounter, and in learning more about the traumatic reaction to past violent events, it is possible to open in the individual and the community new possibilities for change. And it is possible through the psychoanalytic practice, testimony, to speak out about a crisis in the former Yugoslavia that, as trauma necessarily yet persists, is not over (Riding 2017a). Twenty years after the Srebrenica genocide, as the documentary-poetry film Bridges <Bosnia 20> contends, there is still a necessity for art that aims to understand and alleviate psychic trauma in the former Yugoslavia. Though "the difficulty of listening to and responding to traumatic stories in a way that does not lose their impact, that does not reduce them to clichés or turn them all into versions of the same story, remains a problem" (Caruth 1995, vii).

And indeed to avoid repeating the same story, Bridges <Bosnia 20> acts in contradistinction to the sites of commemoration, cemeteries and monuments present in the landscape, which often remember only a single ethnic group - reinforcing the geopolitical categories that the murderers imposed on their victims (Bieber 2006). People are remembered as Bosnian Serb, Bosnian Croat, or Bosniak, as Orthodox, Catholic, or Muslim. Not as fathers, mothers, daughters, or sons. There are few common sites of commemoration or collective spaces to remember the victims of war. What is more, remembering has become a political statement, as those mourning are categorised and enfolded within persistent ethnic and identitarian narratives (Riding 2015a). Commemorative practices, of course, often reflect and consolidate the interests of power, in so far as the past becomes leashed to the services of new state and nation building (Hung 1991; Young 1993; Esbenshade 1995). As such, in Bridges <Bosnia 20> we evoke poets who have in their work attempted to rob war of its last shred of glory, from Wilfred Owen during World War I to the poets of present-day Bosnia-Herzegovina (Arsenijević 2010, 2011). For unlike the poems that are written during and after conflict, most monuments shamefully lack the nerve to project the awful purpose of themselves (Sebald 1999). They are a betrayal of the dead: victims of an incapacity, century just past, to devise a commemorative mode - a century that, more than any other, needed such a mode (Riding 2015b, 2016b). Most memorials are inimical to meditative remembrance (Riding 2015a). Bridges <Bosnia 20> for this reason contends that there is a poetics that can be harnessed in post-conflict regions, as poems can create an affective response in the individual: the shock of the poetic (Jergović 2004; Hemon 2013).

This affective response, is ultimately what this article and the documentary-poetry film Bridges $<$ Bosnia 20> attend to within the discipline of geography, through an opening up of geographic methodology to include artistic responses to a place and landscape: what could be viewed as a cultural form of performing, enacting, or indeed deconstructing geopolitics (Hawkins 2013a, 2013b, 2015a, 2015b). This opening up, of what a geographer does in-place via ethnographic research, as such, enables a giving back to place after conflict: an 'appropriate gesture' (Taussig 2006). Recent geographical work, post non-representational theory (Thrift 2008), on landscape, perception, embodiment (Ingold 1993; Tilley 1994; Edensor 2000; Wylie 2002, 2005), memory (Lorimer \& McDonald 2002; Pile 2002; Lorimer 2003, 2006; Jones 2005; Pearson 2006), material culture, and the spectral (Cook et al. 2004; Edensor 2005; Till 2005; De Silvey 2006, 2007), has pointed towards the use of art in geographic explorations of landscapes, cities, and places (see also for work on filmic geographies, Jacobs 2013, 2016). This article reconsiders this work, and argues that these 'new' artistic responses to place and landscape could be refashioned into a broader 'cultural geopolitics', a 'radical cultural geography' incorporating a material and sensuous attentiveness as a method of critical socio-political analysis (Ingram 2009, 2011, 2012, 2016; Cosgrove 1983, 1985, 2001, 2008).

And as such, in this article we necessarily reposition research which is concerned with aesthetics, affect, and performance, arguing that it is/was an inevitable progression of a more deconstructive, textual and visual 'new cultural geography', which had left some of its humanistic roots behind (Cosgrove \& Jackson 1987; Cosgrove \& Daniels 1988). The accompanying narrative to the documentarypoetry film produced here, is for this reason reminiscent of a form of a non-representational (Thrift 2008), embodied (Ingold 1993), landscape geography (Wylie 2007), which has emerged in the past decade and a half. Yet it relocates this work to a region of the world where, in which, it perhaps seems to some to be out-of-place. For importantly here, the more recent non-representational, embodied, 
landscape geography, which emerged after the 'new cultural geography', enables a disruptive literary approach. Drawing from the raw and immediate qualities of memoir, it transfers an affective moment in the lived landscape, other to the emotionless analytical expository writing common in much geographical research (Sebald 1999; Jergović 2004; Hemon 2013).

Indeed, conveying directly, descriptive impressions, flattens the gaze of the geographer (Toal 1996; Perec 2008, 2010), transferring in the process an affective moment to the reader, appropriate for documenting a 'post-conflict place' because they are situated words. They are contextual, and add a dense weight to the fact that placing and describing conflict and trauma matters (Caruth 1995). Reembracing a situated, embodied, expressive form of geographical inquiry, allows for a writing of place, citizens, politics, and as such it reveals the patterns that led to conflict occurring here (Merrifield 1995). The words themselves on-the-page and the films re-presented here, are defiantly 'in and of the world', in order to demonstrate the significant affective power of representational acts post-conflict (Dewsbury et al. 2002). Furthermore, these relatively under-processed and under-used impressions ask wider political questions of how geopolitical conflicts are written of, represented, and transferred across political borders, in the realm of the spectacle.

\section{Acknowledgements}

The authors would like to thank the Leverhulme Trust for funding this research. Stuart Laycock for sharing his films with us, and for recording his poetry to include in the documentary-poetry film Bridges $<$ Bosnia 20>. Simon Barraclough, for recording his poem I declare this poem a safe zone to use as part of the documentary-poetry film Bridges $\langle$ Bosnia 20>. Dr. Kirsi Pauliina Kallio, for encouraging us to write this piece and to send it to Fennia. Dr. Alex Jeffrey and Professor Tarja Väyrynen for reading the article and suggesting some further reading. And most of all, we would like to acknowledge all of the people who appear in Bridges <Bosnia 20>.

\section{References}

Agnew, J.A. (2016) Spatializing politics. Territory, Politics, Governance 4(3) 265-268. https://doi.org/10.1 080/21622671.2016.1155874

Anderson, B. (1983) Imagined communities: reflections on the origin and spread of nationalism. Verso, London.

Arsenijević, D. (2010) Forgotten future: the politics of poetry in Bosnia and Herzegovina. Nomos, BadenBaden.

Arsenijević, D. (2011) Mobilising unbribable life. In Mousley, A. (ed.) Towards a new literary humanism, 166-181. Palgrave Macmillan, Basingstoke.

Arsenijević, D. (ed.) (2014) Unbribable Bosnia and Herzegovina: the struggle for the commons. Nomos, Baden-Baden.

Baillie, B. (2013) Capturing facades in "conflict-time": structural violence and the (re)construction of Vukovar's churches. Space and Polity 17(3) 300-319. https://doi.org/10.1080/13562576.2013.854996

Barraclough, S. (2008) Los Alamos mon amour. Salt, London.

Barraclough, S. (2010) Bonjour tetris. Penned in the Margins, London.

Barraclough, S. (2011) Neptune blue. Salt, London.

Barraclough, S. (2015) Sunspots. Penned in the Margins, London.

Barraclough, S., Dixon, I. \& McCabe, C. (2013) The debris field. Sidekick Books, London.

Baudrillard, J. (1994) Simulacra and simulation. University of Michigan Press, Michigan.

Baudrillard, J. (1995) The gulf war did not take place. Indiana University Press, Bloomington.

Belloni, R. (2009) Bosnia: Dayton is dead! Long live Dayton!. Nationalism and Ethnic Politics 15(3) 355375. https://doi.org/10.1080/13537110903372367

Benjamin, W. (2016) The storyteller. London, Verso.

Bennett, T. \& Watson, D. (eds.) (2002) Understanding everyday life. Wiley Blackwell, Oxford.

Berger, J. (1972). Ways of seeing. London, Penguin.

Bieber, F. (2006) Post-war Bosnia: ethnicity, inequality and public sector governance. Palgrave Macmillan, Hampshire.

Boal, I.A., Clark, T.J, Matthews, J. \& Watts, M. (2005) Afflicted powers: capital and spectacle in a new age of war. Verso, London. 
Bondi, L. (1999) Stages on journeys: some remarks about human geography and psychotherapeutic practice. The Professional Geographer 51 11-24. https://doi.org/10.1111/0033-0124.00141

Brenner, N. \& Elden, S. (2009) Henri Lefebvre on state, space and territory. International Political Sociology 3(4) 353-377. https://doi.org/10.1111/j.1749-5687.2009.00081.x

Brubaker, R. (2002) Ethnicity without groups. European Journal of Sociology $43163-189$. https://doi. org/10.1017/S0003975602001066

Bunge, W. (1971) Fitzgerald: geography of a revolution. Schenkman Pub. Co., Cambridge, MA.

Butler, J. (2010) Frames of war: when is life grievable? Verso, London.

Callard, F. (2003) The taming of psychoanalysis in geography. Social and Cultural Geography 4 295-312. https://doi.org/10.1080/14649360309071

Campbell, D. (1998) National deconstruction: violence, identity, and justice in Bosnia. University of Minnesota Press, Minneapolis.

Campbell, D. (1999) Apartheid cartography: the political anthropology and spatial effects of international diplomacy in Bosnia. Political Geography 18 395-435. https://doi.org/10.1016/S09626298(98)00110-3

Carter, F.W. (ed.) (1977) An historical geography of the Balkans. Academic, London.

Caruth, C. (ed.) (1995) Trauma: explorations in memory. Baltimore, MD, Johns Hopkins University Press.

Castree, N. \& Macmillan, T. (2004) Old news: representation and academic novelty. Environment and Planning A 36(3) 469-480. https://doi.org/10.1068/a3656

Cook, I. (2004) Follow the thing: papaya. Antipode 36 642-664. https://doi. org/10.1111/j.1467-8330.2004.00441.x

Cosgrove, D. (1983) Towards a radical cultural geography: problems of theory. Antipode 15(1) 1-11. https://doi.org/10.1111/j.1467-8330.1983.tb00318.x

Cosgrove, D. (1985) Social formation and the symbolic landscape. University of Wisconsin Press, Madison.

Cosgrove, D. (2001) Apollo's eye: a cartographic genealogy of the earth in the Western imagination. John Hopkins University Press, Baltimore.

Cosgrove, D. (2008) Geography and vision: seeing, imagining and representing the world. IB Taurus, London.

Cosgrove, D. \& Daniels, S. (1988) The iconography of landscape. Cambridge University Press, Cambridge.

Cosgrove, D. \& Jackson, P. (1987) New directions in cultural geography. Area 19(2) 95-101. http://www. jstor.org/stable/20002425

Crampton, J. (1996) Bordering on Bosnia. GeoJournal 39(4) 353-361. https://doi.org/10.1007/BF02428498

Cresswell, T. (2010) New cultural geography - an unfinished project? Cultural Geographies 17(2) 169174. https://doi.org/10.1177/1474474010363845

Daniels, S. (2006) Suburban pastoral: strawberry Fields forever and Sixties memory. Cultural Geographies 13(1) 28-54. https://doi.org/10.1191/1474474005eu349oa

Daniels, S. (2012) Until the end of days: narrating landscape and environment. Cultural Geographies 19(1) 3-9. https://doi.org/10.1177/1474474011432520

Debord, G. (1967) La société du spectacle. Buchet-Chastel, Paris.

de Certeau, M. (1984) The practice of everyday life. University of California Press, Berkeley.

DeSilvey, C. (2006) Observed decay: Telling stories with mutable things. Journal of Material Culture 11(3) 318-338. https://doi.org/10.1177/1359183506068808

DeSilvey, C. (2007) Salvage memory: constellating material histories on a hardscrabble homestead. Cultural Geographies 14(3) 401-424. https://doi.org/10.1177/1474474007078206

Desilvey, C. (2010) Memory in motion: soundings from Milltown, Montana. Social and Cultural Geography 11(5) 491-510. https://doi.org/10.1080/14649365.2010.488750

DeSilvey, C. (2012) Making sense of transience: an anticipatory history. Cultural Geographies 19(1) 30 53. https://doi.org/10.1177/1474474010397599

Dewsbury, J.D., Harrison, P., Rose, M. \& Wylie, J. (2002) Enacting geographies. Geoforum 33(4) 437-440. https://doi.org/10.1016/S0016-7185(02)00029-5

Didi-Huberman, G. (2008) Images in spite of all: four photographs from Auschwitz. University of Chicago Press, Chicago.

Dubow, J. (2001) Rites of passage: travel and the materiality of vision at the Cape of Good Hope. In Bender B. \& Winer M. (eds.) Contested landscapes: movement, exile and place, 241-255. Berg, Oxford and New York.

Dubow, J. (2011) Still-life, after-life: W.G. Sebald and the demands of landscape. In Daniels S., DeLyser, D., Entrikin, J.N. \& Richardson, D. (eds.) Envisioning landscapes, making worlds: geography and the humanities, 188-198. Routledge, London

Dymitrow, M. (2017) Degradation, restitution and the elusive culture of rural-urban thinking. Fennia 195(1) 36-60. https://doi.org/10.11143/fennia.60462

Edensor, T. (2000) Walking in the British countryside: reflexivity, embodied practices and ways to escape. Body and Society 6(3-4) 81-106. https://doi.org/10.1177/1357034X00006003005 
Edensor, T. (2005) The ghosts of industrial ruins: ordering and disordering memory in excessive space. Environment and Planning D: Society and Space 23 829-849. https://doi.org/10.1068/d58j

Edensor, T. (2008) Mundane hauntings: commuting through the phantasmagoric working class spaces of Manchester, England. Cultural Geographies 15313-333. https://doi.org/10.1177/14744744008091330

Edkins, J. (2003) Trauma and the memory of politics. Cambridge University Press, Cambridge.

Elden, S. (2013) The birth of territory. University of Chicago Press, Chicago.

England, K. (1994) Getting personal: reflexivity, positionality, and feminist research. The Professional Geographer 46(1) 80-89. https://doi.org/10.1111/j.0033-0124.1994.00080.x

Erikson, K. (1995) Notes on trauma and community. In Caruth, C. (ed.) Trauma: explorations in memory, 183-199. Johns Hopkins University Press, Baltimore, MD.

Esbenshade, R.S. (1995) Remembering to forget: memory, history, national identity in postwar EastCentral Europe. Representations 49 72-96. https://doi.org/10.1525/rep.1995.49.1.99p0265t

Felman, S. \& Laub, D. (1992) Testimony: crises of witnessing in literature, psychoanalysis and history. Routledge, London.

Felman, S. (2002) The juridical unconscious: trials and traumas in the twentieth century. Harvard University Press, Cambridge, Massachusetts.

Foucault, M. (1975) Discipline and punish: the birth of the prison. Random House, New York, NY.

Gilbert, A. \& Mujanović, J. (2015) Dayton at twenty: towards new politics in Bosnia-Herzegovina. Southeast European and Black Sea Studies 15(4) 605-610. https://doi.org/10.1080/14683857.2015.1130359

Glenny, M. (1992) The fall of Yugoslavia. Penguin, London.

Glenny, M. (1999) The Balkans, 1804-1999: nationalism, war and the great powers. Granta, London.

Goldsworthy, V. (1998) Inventing Ruritania: the imperialism of the imagination. Yale University Press, London.

Gordy, E. (2015) Dayton's Annex 4 Constitution at 20: political stalemate, public dissatisfaction and the rebirth of self-organisation. Southeast European and Black Sea Studies 15(4) 611-622. https://doi.or g/10.1080/14683857.2015.1134132

Harley, J.B. (1989) Deconstructing the map. Cartographica 26(2) 1-20. https://doi.org/10.3138/E6357827-1757-9T53

Hawkins, H. (2013a) Geography and art, an expanding field: site, the body and practice. Progress in Human Geography 37(1) 52-71. https://doi.org/10.1177/0309132512442865

Hawkins, H. (2013b) For creative geographies: geography, visual arts and the making of worlds. Routlegde, London.

Hawkins, H. (2015a) Creative geographic methods: knowing, representing, intervening. Cultural Geographies 22(2) 247-268. https://doi.org/10.1177/1474474015569995

Hawkins, H. (2015b) Creativity. Routledge, London.

Helms, E. (2013) Innocence and victimhood: gender, nation, and women's activism in postwar BosniaHerzegovina. University of Wisconsin Press, Madison.

Hemon, A. (2013) The book of my lives. Farrar, Straus and Giroux, New York, NY.

Holloway, L. \& Hubbard, P. (2000) People and place: the extraordinary geography of everyday life. Prentice Hall, New York, NY.

Horvat, S. \& Štiks, I. (eds.) (2015) Welcome to the desert of post-socialism: radical politics after Yugoslavia. Verso, London.

Hromadžić, A. (2015) Citizens of an empty nation: youth and state-making in postwar Bosnia-Herzegovina. University of Pennsylvania Press, Philadelphia.

Hung, W. (1991) Tiananmen Square: a political history of monuments. Representations 35 84-117. https://doi.org/10.1525/rep.1991.35.1.99p00662

Ingold, T. (1993) The temporality of the landscape. World Archaeology 25 152-174. https://doi.org/10.1 080/00438243.1993.9980235

Ingram, A. (2009) Art and the geopolitical: remapping security at Green Zone/Red Zone. In Ingram, A. \& Dodds, K. (eds.) Spaces of security and insecurity: geographies of the war on terror, 257-277. Ashgate, Farnham.

Ingram, A. (2011) Making geopolitics otherwise: artistic interventions in global political space. Geographical Journal 177(3) 218-222. https://doi.org/10.1111/j.1475-4959.2011.00415.x

Ingram, A. (2012) Experimental geopolitics: Wafaa Bilal's domestic tension. Geographical Journal 178(2) 123-133. https://doi.org/10.1111/j.1475-4959.2011.00455.x

Ingram, A. (2016) Rethinking art and geopolitics through aesthetics: artist responses to the Iraq war. Transactions of the Institute of British Geographers 41(1) 1-13. https://doi.org/10.1111/tran.12099

Jacobs, J. (2013) Listen with your eyes; towards a filmic geography. Geography Compass 7(10) 714-728. https://doi.org/10.1111/gec3.12073

Jacobs, J. (2016) Filmic geographies: the rise of digital film as a research method and output. Area 48(4) 452-454. https://doi.org/10.1111/area.12309 
Jansen, S. (2015) Yearning in the meantime: 'normal lives' and the state in a Sarajevo apartment complex. Berghahn, Oxford.

Jeffrey, A. (2006) Building state capacity in post-conflict Bosnia and Herzegovina: the case of Brčko District. Political Geography 25 203-227. https://doi.org/10.1016/j.polgeo.2005.11.003

Jeffrey, A. (2013) The improvised state: sovereignty, performance and agency in Dayton Bosnia. Wiley Blackwell, London.

Jeffrey, A. \& Jakala, M. (2014) The hybrid legal geographies of a war crimes court. Annals of the Association of American Geographers 104(3) 652-667. https://doi.org/10.1080/00045608.2014.892365

Jergović, M. (2004) Sarajevo Marlboro. Archipelago Books, Brooklyn, NY.

Jergović, M. (2016) The siege starts without warning. New York Times 21.10.2016. <http://www.nytimes. com/2016/10/23/opinion/the-siege-starts-without-warning.html? $r=0>01.12 .2016$.

Jones, O. (2005) An emotional ecology of memory, self and landscape. In Davidson, J., Bondi, L. \& Smith, M. (eds.) Emotional geographies, 205-218. Ashgate, Oxford.

Kingsbury, P. (2004) Psychoanalytic approaches. In Duncan, J.S. Johnson, N.C. \& Schein, R.H. (eds.) A companion to cultural geography, 108-120. Blackwell, Oxford.

Kingsbury, P. \& Pile, S. (eds.) (2014) Psychoanalytic geographies. Ashgate, Farnham.

Kraft, M.G. (2015) Insurrections in the Balkans: from workers and students to new political subjectivities. In Horvat, S. \& Štiks, I. (eds.) Welcome to the desert of post-socialism: radical politics after Yugoslavia, 216-217. Verso, London.

Kurtović, L. (2015) 'Who sows hunger, reaps rage': on protest, indignation and redistributive justice in post-Dayton Bosnia-Herzegovina. Southeast European and Black Sea Studies 15 (4) 639-659. https:// doi.org/10.1080/14683857.2015.1126095

Latour, B. (2007) Reassembling the social. Oxford University Press, New York.

Laub, D. (1995) Truth and testimony: the process and the struggle. In Caruth, C. (ed.) Trauma: explorations in memory, 61-75. Johns Hopkins University Press, Baltimore, MD.

Laycock, S. (2015) Zone: poems of the Bosnian war. Mica Press, Colchester.

Little, A. \& Silber, L. (1996) The death of Yugos/avia. Penguin, London.

Lorimer, H. (2003) Telling small stories: spaces of knowledge and the practice of geography. Transactions of the Institute of British Geographers 28(2) 197-217. https://doi.org/10.1111/1475-5661.00087

Lorimer, H. (2006) Herding memories of humans and animals. Environment and Planning D: Society and Space 24 497-518. https://doi.org/10.1068/d381t

Lorimer, H. (2012) Memoirs for the earth: Jacquetta Hawkes's literary experiments in deep time. Cultural Geographies 19(1) 87-106. https://doi.org/10.1177/1474474011432377

Lorimer, H. \& MacDonald, F. (2002) Rescue archaeology, Taransay, Scotland. Cultural Geographies 9 95-103. https://doi.org/10.1191/1474474002eu235oa

Lorimer, H. \& Wylie, J. (2010) Loop (a geography). Performance Research 15(4) 6-13. https://doi.org/10. $1080 / 13528165.2010 .539872$

Luthar, B. \& Puznik, M. (2010) Remembering utopia: the culture of everyday life in socialist Yugoslavia. New Academia Publishing, Washington DC.

Maddrell, A. \& Sidaway, J. (2010) Deathscapes: spaces for death, dying, mourning and remembrance. Routledge, London.

Majstorović, D., Vučkovac, Z. \& Pepić, A. (2015) From Dayton to Brussels via Tuzla: post-2014 economic restructuring as Europeanization discourse/practice in Bosnia and Herzegovina. Southeast European and Black Sea Studies 15(4) 661-682. https://doi.org/10.1080/14683857.2015.1126093

Matless, D. (2008) A geography of ghosts: the spectral landscapes of Mary Butts. Cultural Geographies 15(3) 335-358. https://doi.org/10.1177/1474474008091331

Matless, D. (2010) Describing landscape: regional sites. Performance Research 15(4) 72-82. https://doi. org/10.1080/13528165.2010.539882

Matless, D. (2014) In the nature of landscape: cultural geography on the Norfolk Broads. Wiley Blackwell, London.

Mazower, M. (2002) The Balkans: from the end of Byzantium to the present day. Phoenix, London.

Merrifield, A. (1995) Situated knowledge through exploration: reflections on Bunge's "geographical expeditions". Antipode 27(1) 49-70. https://doi.org/10.1111/j.1467-8330.1995.tb00261.x

Mieszkowski, J. (2012) Watching war. Stanford University Press, Palo Alto, CA.

Mitchell, K. \& Kallio, K.P. (2017) Spaces of the geosocial: exploring transnational topologies. Geopolitics 22(1) 1-14. https://doi.org/10.1080/14650045.2016.1226809

Mujkić, A. (2015) In search of a democratic counter-power in Bosnia-Herzegovina. Southeast European and Black Sea Studies 15(4) 623-638. https://doi.org/10.1080/14683857.2015.1126094

Murtagh, C. (2016) Civic mobilization in divided societies and the perils of political engagement: Bosnia and Herzegovina's protest and plenum movement. Nationalism and Ethnic Politics 22(2) 149-171. https://doi.org/10.1080/13537113.2016.1169060

Nancy, J-L. (2000) Being singular plural. Stanford University Press, Palo Alto, CA. 
Nancy, J-L. (2005) The ground of the image. Fordham University Press, New York, NY.

Nast, H. (2000) Mapping the 'unconscious': racism and the oedipal family. Annals of the Association of American Geographers 90 215-255. https://doi.org/10.1111/0004-5608.00194

Pearson, M. (2006) "In comes I": performance, memory, and landscape. University of Exeter Press, Exeter.

Perec, G. (2008) Species of spaces and other essays. Penguin Classics, London.

Perec, G. (2010) An attempt at exhausting a place in Paris. Wakefield Press, New York.

Philo, C. \& Parr, H. (2003) Introducing psychoanalytic geographies. Social and Cultural Geography 4 283-293. https://doi.org/10.1080/14649360309074

Pile, S. (1991) Practising interpretive geography. Transactions of the Institute of British Geographers 16 458-469. https://www.jstor.org/stable/623030

Pile, S. (1996) The body and the city: psychoanalysis, space and subjectivity. Routledge, New York.

Pile, S. (2002) Memory and the city. In Campbell, J. \& Harbord, J. (eds.) Temporalities, autobiography and everyday life. Manchester University Press, Manchester.

Pink, S. (2001) Doing visual ethnography. Sage, London.

Riding, J. (2015a) Landscape, memory, and the shifting regional geographies of northwest BosniaHerzegovina. GeoHumanities 1(2) 378-397. https://doi.org/10.1080/2373566X.2015.1093917

Riding, J. (2015b) Death drive: final tracings. In Hawkins, H. \& Straughan, E. (eds.) Geographical aesthetics: imagining space, staging encounters, 181-196. Ashgate, Farnham.

Riding, J. (2016a) A new regional geography of a revolution: Bosnia's plenum movement. Territory, Politics, Governance [online Dec 07 2016] https://doi.org/10.1080/21622671.2016.1260491

Riding, J. (2016b) A geographical biography of a nature writer. Cultural Geographies 23(3) 387-399. https://doi.org/10.1177/1474474015591124

Riding, J. (2017a) Geographical testimony: a short history of a Yugoslav family. Journal of Cultural Geography 34(2) 250-267. https://doi.org/10.1080/08873631.2016.1237609

Riding, J. (2017b) Representing a divided place: the artistic-military practice of Mladen Miljanović. Cultural Geographies 24(1) 171-180. https://doi.org/10.1177/1474474016647372

Rieff, D. (1995) Slaughterhouse: Bosnia and the failure of the West. Vintage Random House, London.

Rieff, D. (2011) Against remembrance. Melbourne University Press, Melbourne.

Rieff, D. (2016) In praise of forgetting: historical memory and its ironies. Yale University Press, New Haven, CT.

Robinson, J. (2003) Political geography in a postcolonial context. Political Geography 22(6) 647-651. https://doi.org/10.1016/S0962-6298(03)00072-6

Rose, G. (1997) Situating knowledges: positionality, reflexivities, and other tactics. Progress in Human Geography 21(2) 305-320. https://doi.org/10.1191/030913297673302122

Rose, G. (2012) Visual methodologies: an introduction to researching with visual materials. Sage, London.

Rose, M. (2012) Dwelling as marking and claiming. Environment and Planning D: Society and Space 30 (5) 757-771. https://doi.org/10.1068/d6809

Scott, S. (2009) Making sense of everyday life. Polity, Cambridge, UK.

Sebald, W.G. (1999) On the natural history of destruction. Hamish Hamilton, London.

Snel, G. (2014) The past is always in the present: aether and the returns of history and Europe's new post-1989 peripheries. The cases of Mihail Sebastian's diary and Emir Suljagić's Srebrenica memoir. Neohelicon 41(1) 241-246. https://doi.org/10.1007/s11059-013-0212-y

Sontag, S. (2004) Regarding the pain of others. Penguin Books, London.

Stoker, B. (1897) Dracula. Archibald Constable and Company, Westminster.

Suljagić, E. (2005) Postcards from the grave. Saqi Books, London.

Taussig, M. (2006) Walter Benjamin's grave. University of Chicago Press, Chicago.

Thompson, M. (1992) A paper house: the ending of Yugoslavia. Vintage, London.

Thrift, N. (2008) Non-representational theory: space, politics, affect. Routledge, Oxford.

Till, K. (2005) The new Berlin: memory, politics, place. University of Minnesota Press, Minneapolis.

Tilley, C. (1994) A phenomenology of landscape: places, paths, and monuments. Berg, Oxford.

Toal, G. (1996) An anti-geopolitical eye: Maggie O'Kane in Bosnia, 1992-93. Gender, Place and Culture 3(2) 171-186. https://doi.org/10.1080/09663699650021873

Toal, G. \& Dahlman, C. (2011) Bosnia remade: ethnic cleansing and its reversal. Oxford University Press, Oxford.

Todorova, M. (1997) Imagining the Balkans. Oxford University Press, Oxford.

Touquet, H. (2012) The Republika Srpska as a strong nationalizing state and the consequences for postethnic activism. Nationalities Papers: The Journal of Nationalism and Ethnicity 40(2) 203-220. https://doi.org/10.1080/00905992.2011.652609

Touquet, H. (2015) Non-ethnic mobilisation in deeply divided societies: the case of the Sarajevo Protests. Europe-Asia Studies 67(3) 388-408. https://doi.org/10.1080/09668136.2015.1019430

Van Dyke, C. (2013) Plastic eternities and the mosaic of landscape. Environment and Planning D: Society and Space 31(3) 400-415. https://doi.org/10.1068/d15010 
Väyrynen, T. (2013) Re-thinking peace through the figure of Parrhesiastes: creating agonistic political space. International Journal of Conflict Engagement and Resolution 2 147-162.

Väyrynen, T. (2014) Muted national memory: when the Hitler's brides speak the truth. International Feminist Journal of Politics 16(2) 218-235. https://doi.org/10.1080/14616742.2013.773155

Vulliamy, E. (1994) Seasons in hell: understanding Bosnia's war. St. Martin's Press, New York.

Vulliamy, E. (2013) The war is dead, long live the war: Bosnia: the reckoning. Vintage, London.

Wood, D. (1992) The power of maps. The Guildford Press, New York, NY.

Wylie, J. (2002) An essay on ascending Glastonbury Tor. Geoforum 33 441-454. https://doi.org/10.1016/ S0016-7185(02)00033-7

Wylie, J. (2005) A single days walking: narrating self and landscape on the South West Coast Path. Transactions of the institute of British Geographers 30 37-51. https://doi. org/10.1111/j.1475-5661.2005.00163.x

Wylie, J. (2007) Landscape. Routledge, London.

Young, J.E. (1993) The texture of memory: holocaust memorials and meaning. Yale University Press, New Haven, CT.

Žižek, S. (2000) The fragile absolute: or why is the Christian legacy worth fighting for? Verso, London. 